\title{
NEWSLETTER SEBAGAI MEDIA EDUKASI CEGAH COVID 19 DENGAN MASKER KAIN
}

\author{
Rahmi Susanti $^{1)}$, Aghnia Shabrina ${ }^{2)}$, Lisa Ariana Putri ${ }^{3)}$, Tahsya Erika ${ }^{4)}$, Laila Citra \\ Sandi ${ }^{5)}$
}

${ }^{1)}$ Fakultas Kesehatan Masyarakat, Universitas Mulawarman email: rahmi.susanti@fkm.unmul.ac.id

${ }^{2-5)}$ Fakultas Kesehatan Masyarakat, Universitas Mulawarman

\begin{abstract}
ABSTRAK
Jumlah kasus terkonfirmasi di Kabupaten Kutai Kartanegara sebanyak 2.550 kasus, dengan penyumbang kasus terbanyak berasal dari kecamatan Tenggarong yakni dengan total kasus positif sebesar 692 kasus. Salah satu kelurahan dengan kasus terkonfirmasi adalah kelurahan Loa ipuh dengan kondisi belum terdapat media edukasi terkait pencegahan COVID-19 khususnya di RT 45. Berdasarkan hasil survei, diperoleh informasi bahwa 27,3\% penduduk belum mematuhi protokol Kesehatan, $15,9 \%$ berpendapat bahwa tidak perlu menggunakan masker saat keluar rumah dan 20,5\% memiliki opini bahwa masker tidak dapat melindungi diri dari infeksi COVID-19. Jenis masker yang paling banyak dipilih oleh warga adalah masker kain yakni sebanyak 52,2\%. Edukasi tentang bagaimana cara menggunakan dan membersihkan masker kain dengan tepat sangat dibutuhkan oleh para pengguna masker kain agar manfaat yang diperoleh lebih efektif dalam pencegahan infeksi COVID-19. Newslettter merupakan salah satu media informasi dengan tujuan untuk menyampaikan informasi singkat dengan sasaran pembaca yang sibuk atau tidak memiliki waktu yang banyak dalam membaca sebuah berita. Dalam menyampaikan edukasi kepada masyarakat untuk menghindari kontak fisik maka diberikan newsletter yang berisi informasi fungsi singkat masker kain dan bagaimana menjaga kebersihan masker kain yang dapat digunakan berulang kali. Newsletter ini dibagikan kepada 47 kepala keluarga di RT 45 kelurahan Loa Ipuh. Masyarakat bersedia menerima dan membaca newsletter yang diberikan.
\end{abstract}

Kata kunci: Newsletter, Masker Kain, COVID-19

\section{ABSTRACT}

The number of confirmed cases in Kutai Kartanegara Regency is 2,550 cases, with the largest contributor to cases coming from Tenggarong sub-district with a total of 692 positive cases. One of the sub-districts with confirmed cases is Loa ipuh with no educational media related to the prevention of COVID-19, especially in RT 45. Based on the survey results, information was obtained that $27.3 \%$ of the population had not complied with the Health protocol, $15.9 \%$ thought that they did not need to use a mask when leaving the house and $20.5 \%$ have the opinion that masks cannot protect themselves from COVID-19 infection. The type of mask that was mostly chosen by residents was fabric masks, namely as much as $52.2 \%$. Education on how to use and clean cloth masks appropriately is needed by fabric mask users so that the benefits they get are more effective in preventing COVID-19 infection. Newslettter is one of the information media with the aim of conveying brief information to the target audience who are busy or do not have much time to read news. In delivering education to the public to avoid physical contact, a newsletter is provided which contains information on brief functions of fabric masks and how to keep fabric masks clean which can be used repeatedly. This newsletter was distributed to 47 family heads in RT 45 Kelurahan Loa Ipuh. The public is willing to accept and read the newsletter given

Keywords: Newsletter, Fabric Mask, COVID-19

\section{PENDAHULUAN}

Kabupaten kutai kartanegara merupakan
COVID-19 dengan jumlah kasus positive mencapai 3.418, kasus meninggal 65 orang,

salah satu wilayah yang terdampak pandemik 
kasus sembuh mencapai 2.803. hingga saat ini terdapat 550 kasus aktif COVID-19 [1].

Fase relaksasi pada masa pandemic dalam wilayah Kutai Kartanegara telah berlangsung lebih dari 3 bulan yakni sejak 04 Juni 2020, upaya yang dilakukan untuk menurunkan laju penularan COVID-19 adalah testing pada masyarakat, tracing kontak erat pasien terkonfirmasi positif hingga mempersiapkan treatment bagi masyarakat yang terjangkit [2].

Gugus tugas COVID-19 juga memberikan himbauan untuk melakukan 3M yakni memakai masker, mencuci tangan dan menjaga jarak kepada masyarakat di Kutai Kartanegara. Hasil survei dan observasi di salah satu kelurahan Kabupaten Kutai Kartanegara yakni kelurahan loa ipuh khususnya pada warga RT 45 adalah warga menyatakan memperoleh informasi berupa data dan pesan Kesehatan terkait COVID-19 dari puskesmas loa ipuh, 36,4\% menyatakan sedikit megetahui tentang gejala COVID-19, $27,3 \%$ menyatakan belum mematuhi protocol Kesehatan selama COVID-19, 15,9\% belum menggunakan masker saat keluar rumah, $20,5 \%$ menyatakan pendapat bahwa masker tidak bisa melindungi diri dari infeksi COVID-19 dan rata-rata masker yang dimiliki warga berjenis masker kain.

Data eksperimental dan epidemiologi mendukung tindakan penggunaan masker pada masyarakat untuk mengurangi dampak penyebaran virus. Terdapat keuntungan secara personal jika individu menggunakan masker ditengah-tengah masyarakat [3].
Masker memiliki kemampuan untuk melindungi pemakainya dari adanya parikel infeksius, ataupun berguna sebagai source control yaitu membatasi penyebaran droplet yang dikeluarkan oleh pemakainya ke udara [4].

Beberapa penelitian menunjukkan hasil bahwa efektivitas penggunaan masker kain wajah lebih rendah dibandingkan masker medis, namun meski dari segi khasiatnya lebih rendah, perlu diperhatikan bahwa penggunaan masker kain masih dapat menyaring virus. Filtrasi dari masker kain tergantung dari bahannya dan masker yang terbuat dari bahan polyester dianggap paling efektif [5].

Hasil analisis situasi berdasarkan data survei dan observasi juga beberapa penelitian, menunjukkan betapa pentingnya penggunaan masker kain dan tentu saja masyarakat membutuhkan informasi terkait bagaimana merawat masker kain selama masa pandemic berlangsung.

Hasil focus group discussion menunjukkan fakta dilapangan bahwa masyarakat menggunakan masker lebih dari 4 jam diluar rumah, tidak langsung mencuci masker setelah digunakan dan hanya menjemur atau digantung setelah digunakan. Hasil observasi juga menunjukkan belum ada spanduk ataupun media cetak lainnya yang diberikan oleh tenaga Kesehatan terkait edukasi covid-19 dan khususnya tentang panduan pengunaan dan perawatan masker kain. 
Hal ini melatarbelakangi tim untuk melaksanakan edukasi dengan menggunakan media newsletter berisi pedoman penggunaan dan perawatan masker kain dalam mencegah COVID-19 di RT 45 Kelurahan Loa Ipuh Kecamatan Tenggarong, Kabupaten Kutai Kartanegara.

\section{METODE PELAKSANAAN KEGIATAN}

Kegiatan ini dilaksanakan selama kurang lebih 4 hari meliputi perencanaan, pembuatan media newsletter, melakukan koordinasi dengan Bapak Ketua RT 45 hingga melakukan pembagian newsletter kepada warga dengan mengikuti protokol Kesehatan yakni menjaga jarak, menggunakan masker dan tidak bertemu secara langsung. Selain itu dilakukan tambahan kegiatan yakni pembagian masker kain. Media newsletter juga akan ditempelkan di tempat tempat umum seperti posyandu, pos siskamling dan beberapa tempat yang banyak dilewati oleh warga.

Populasi sasaran berjumlah 98 Kepala Keluarga, untuk mengurangi kemungkinan interaksi diluar rumah terlalu banyak, maka dilakukan perhitungan besar sampel untuk membatasi jumlah kepala keluarga yang menjadi sasaran,

$$
n=\frac{Z_{1-\alpha / 2}^{2} \cdot P\left(1-P^{\prime}\right) \cdot N}{d^{2} \cdot(N-1)+Z_{1-\alpha / 2}^{2} \cdot P(1-P)}[6]
$$

Maka besar sampel sasaran kegiatan adalah 47 kepala keluarga. 47 KK ini dipilih dengan Teknik purposive sampling dengan media yang digunakan berupa newsletter yang telah melewati hasil review expert dan dilakukan juga penilaian dari masyarakat penerima.

Pengumpulan data responden dilakukan dengan memanfaatkan nomor whatsapp untuk mengirimkan google form evaluasi media.

\section{HASIL DAN PEMBAHASAN}

Newsletter adalah bentuk paling umum dari publikasi periodic. Media ini relatif mudah, murah dan cepat untuk diproduksi. Fungsi newsletter adalah memberi doronga, media komunikasi, media publikasi, wahana penjalin hubungan dan representative citra korporat.

Gerakan pembagian masker dan newsletter yang dilakukan oleh Tim dari Fakultas Kesehatan Universitas Mulawarman merupakan salah satu dukungan untuk membantu pemerintah dalam mencegah penyebaran Covid-19 dengan menyadarkan masyarakat untuk patuh menggunakan masker pada saat melakukan kegiatan di luar rumah

Penggunaan media ini dipilih karena warga RT 45 mayoritas bekerja sebagai pegawai dan memiliki Pendidikan cukup tinggi dan untuk mengurangi interaksi social ditengah pandemik.

Selain melakukan pemberian media edukasi, tim juga membagikan masker kain kepada 47 kepala keluarga di RT 45.

Berikut merupakan gambar/ tampilan dari newsletter tersebut 


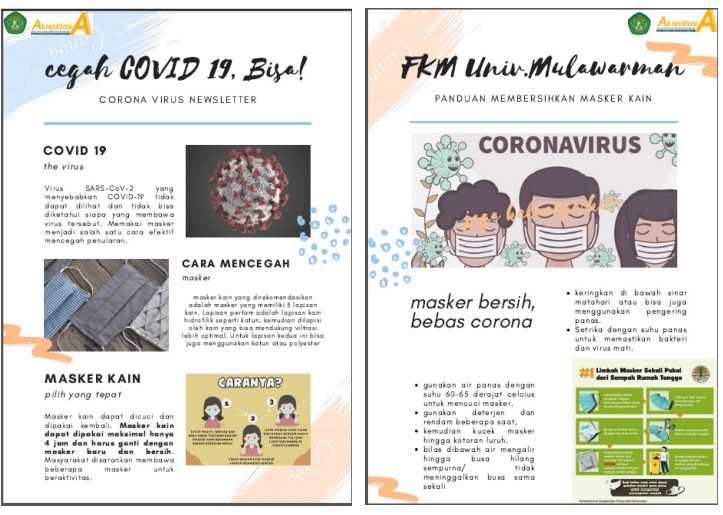

Gambar 1. Newsletter media edukasi cegah covid-19 dengan masker kain

Tampilan pertama berisi informasi singkat tentang COVID-19, cara mencegah dan panduan lama penggunaan masker serta cara penggunaan masker. Bagian kedua berisi panduan cara membersihkan masker kain yang mengadopsi flyer media promosi Kesehatan dari Kementerian Kesehatan RI.

Berikut adalah beberapa dokumentasi pembagian newsletter dilapangan

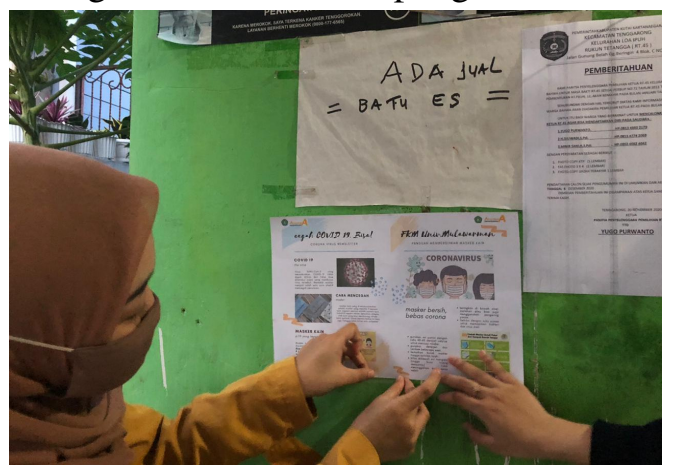

Gambar 2. Newsletter di TTU RT 45

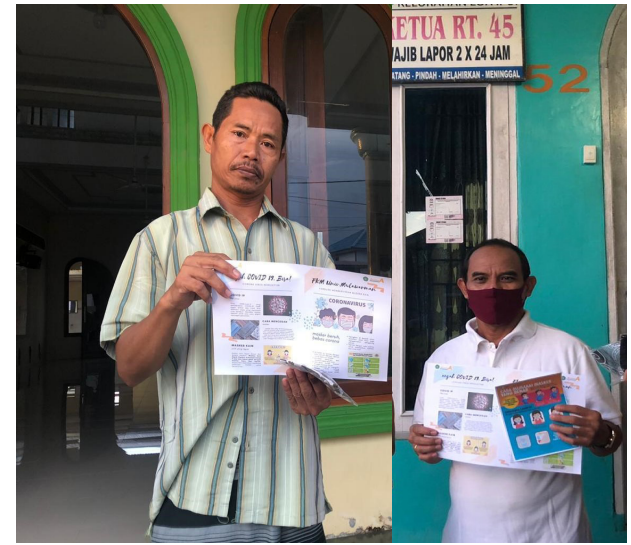

Gambar 3. Newsletter pada pengurus masjid dan Bapak Ketua RT 45
Media yang digunakan telah melewati review expert dan penilaian dari $47 \mathrm{KK}$ di RT 45, berikut adalah hasil penilaian tersebut

Tabel 1. Hasil penilaian warga terhadap media Newsletter

\begin{tabular}{|c|l|c|c|c|}
\hline No & \multicolumn{2}{|c|}{ Kriteria } & \multicolumn{3}{|c|}{ Persentase penilaian } \\
\cline { 3 - 5 } & & Baik & Cukup & Kurang \\
\hline 1 & $\begin{array}{l}\text { Kejelasan isi } \\
\text { materi dan } \\
\text { pesan }\end{array}$ & $91,49 \%$ & $6,38 \%$ & $2,13 \%$ \\
\hline 2 & $\begin{array}{l}\text { Penggunaan } \\
\text { bahasa }\end{array}$ & $91,49 \%$ & $8,51 \%$ & - \\
\hline 3 & $\begin{array}{l}\text { Kejelasan } \\
\text { tulisan }\end{array}$ & $82,98 \%$ & $14,89 \%$ & $2,13 \%$ \\
\hline 4 & $\begin{array}{l}\text { Kejelasan } \\
\text { gambar atau } \\
\text { foto }\end{array}$ & $85,11 \%$ & $14,89 \%$ & - \\
\hline 5 & $\begin{array}{l}\text { Judul utama } \\
\text { dan headline }\end{array}$ & $78,72 \%$ & $21,28 \%$ & - \\
\hline 6 & Sub judul & $80,85 \%$ & $19,15 \%$ & - \\
\hline 7 & Logo & $78,72 \%$ & $19,15 \%$ & $2,13 \%$ \\
\hline 8 & Slogan & $72,34 \%$ & $23,40 \%$ & $4,26 \%$ \\
\hline 9 & $\begin{array}{l}\text { Gradasi warna } \\
\text { background }\end{array}$ & $65,96 \%$ & $31,91 \%$ & $2,13 \%$ \\
\hline 10 & $\begin{array}{l}\text { Gradasi warna } \\
\text { tulisan }\end{array}$ & $80,85 \%$ & $14,89 \%$ & $4,26 \%$ \\
\hline
\end{tabular}

Sumber : data primer tahun 2020

91,49\% masyarakat menyatakan newsletter yang mereka peroleh memiliki kejelasan isi materi dan pesan serta penggunaan Bahasa yang baik walaupun 4,26\% menyatakan kurang pada slogan dan gradasi warna tulisan. Hal ini serupa dengan hasil yang diperoleh dari review expert yakni penggunaan gradasi warna dan efek abstrak dianggap minim serta belum adanya headline, subheadline serta slogan yang tepat pada media yang digunakan.

Fokus utama kegiatan ini adalah masyarakat memperoleh banyak edukasi dan informasi serta bentuk peran serta akademik kepada pusat pelayanan Kesehatan primer setempat sebagai agen pemberi pesan dan informasi Kesehatan dimasa pandemic ini. Kurangnya media yang diberikan dan 
disebarkan yang dibuktikan dari hasil untuk digunakan ketika keluar rumah. observasi menjadi pendorong utama peneliti Adanya kegiatan ini juga meningkatkan untuk melakukan upaya edukasi dengan kesadaran masyarakat tentang pentingnya bantuan media yang murah dan mudah mencegah wabah Covid-19 dengan dipahami oleh warga yang Sebagian besar bekerja sebagai wiraswasta $(27$ KK) dan sisanya adalah ibu rumah tangga serta PNS.

Kelemahan dari luaran ini adalah belum adanya bentuk pre post test yang diberikan kepada warga setelah diberikan perlakuan pemberian media dilapangan. Hal ini dikarenakan keterbatasan social yang harus dijaga dan keterlambataan warga dalam merespon grup whatsapp yang telah dibentuk. Waktu juga menjadi salah kesulitan dilapangan, karena tim memperoleh Batasan yang cukup ketat dari aparatur setempat sehingga menjadi contoh pelaksana protocol Kesehatan selama pandemik.

Peluang dari kegiatan pembagian masker dan newsletter ini mendapatkan penerimaan oleh masyarakat cukup baik dan sangat terbuka bahkan antusias. Hal ini ditunjukkan dengan ekspresi dan informasi yang disampaikan secara langsung kegiatan ini dirasakan sangat bermanfaat karena dapat menambah jumlah masker yang mereka miliki tanpa harus membeli sendiri dan dapat menggunakan masker secara bergantian, terutama bagi warga yang rutinitasnya mengharuskan keluar rumah setiap hari dan bertemu dengan orang luar.

Selain itu, harga masker tergolong mahal, sehingga warga sulit mendapatkan

\section{KESIMPULAN}

1. Pembagian newsletter beserta masker telah memenuhi target yakni disampaikan kepada 47 kepala keluarga di wilayah RT 45 kelurahan loa ipuh dan ditempelkan di tempat tempat umum seperti masjid dan pos siskamling dan lainnya

2. Berdasarkan hasil survei dan observasi diperoleh informasi bahwa penerapan protocol Kesehatan, kesadaran penggunaan masker dan perawatan masker kain masih kurang baik diterapkan oleh warga sehingga kegiatan yang dilakukan telah tepat untuk menambah edukasi Kesehatan di masa pandemic

3. Dampak dari kegiatan ini adalah diperolehnya informasi langsung dari lapangan bahwa edukasi dan informasi yang diberikan atau yang diperoleh oleh masyarakat masih kurang dan banyak terjadi salah pengertian serta kebingungan terkait COVID-19 ini, sehingga dengan adanya kegiatan ini menjadi informasi tambahan untuk dinas Kesehatan setempat dan masyarakat terbantu dengan informasi 
dan edukasi yang diberikan oleh tim dari

fakultas Kesehatan masyarakat universitas mulawarman

\section{SARAN}

Rekomendasi kegiatan yang berikutnya adalah

1. Monitoring dan evaluasi program yang telah terlaksana dilapangan dengan memanfaatkan media online seperti grup whatsapp dan google form sebagai wadah pengisian evaluasi

2. Memberikan pesan dan informasi singkat terkait pentingnya penggunaan masker kain di tempat tempat umum seperti masjid, mushola yang dapat dilakukan setelah beribadah Bersama

3. Selanjutnya dapat dilakukan program edukasi untuk mengembangkan pesan dan informasi terkait menjaga jarak dan mencuci tangan dengan menciptakan jingle tertentu atau memberikan Batasan jarak dengan bantuan cat di tempat tempat umum.

\section{UCAPAN TERIMAKASIH}

Ucapan terimakasih kami ucapkan untuk

1. Pimpinan dan seluruh civitas akademika fakultas Kesehatan masyarakat universitas mulawarman yang telah memberikan dukungan selama kegiatan ini berlangsung
2. Pimpinan puskesmas beserta seluruh staf yang memberikan banyak informasi dan pengarahan selama kegiatan berlangsung

3. Bapak Ketua RT 45 dan ibu kader posyandu sekaligus PKK yang memberikan dukungan, dan membantu tim selama berada dilapangan.

\section{REFERENSI}

[1] Peta dan Data Sebaran Covid-19 KALTIM [Internet]. [cited 2020 Nov 28]. Available from: https://dishub.kukarkab.go.id/sebarancor onakaltim

[2] Pandemi Covid-19 Kutai Kartanegara I Halaman Berita Mengenai Covid-19 Kab. Kukar I KUKAR, Tiga Bulan Pasca Relaksasi [Internet]. [cited 2020 Nov 28]. Available from: https://gugustugas.kukarkab.go.id/blog/71/kukar-tigabulan-pasca-relaksasi

[3] Scientific Brief: Community Use of Cloth Masks to Control the Spread of SARSCoV-2 I CDC [Internet]. [cited $2020 \mathrm{Nov}$ 28]. Available from: https://www.cdc.gov/coronavirus/2019ncov/more/masking-science-sarscov2.html

[4] Howard J, Huang A, Li Z, Rimoin A. Face Masks Against COVID-19: An Evidence Review [Pre-proof]; [not peerreviewed]. Pnas [Internet]. 2020;XXX(July):1-8. Available from: www.preprints.org

[5] Rizki SA, Kurniawan A. Efficacy of cloth face mask in reducing covid-19 transmis $\mathrm{s}$ ion: A literature review. Kesmas. 2020;15(2):43-8.

[6] Ogston SA, Lemeshow S, Hosmer DW, Klar J, Lwanga SK. Adequacy of Sample Size in Health Studies. Biometrics. 1991;47(1):347. 